\title{
THE EFFECT OF AGRICULTURAL EXPORT ON ECONOMIC GROWTH IN NIGERIA (1980-2015): AN IMPULSE RESPONSE FUNCTION ANALYSIS
}

\author{
Binuomote, S. O., Odeyale, T. A. \\ Department of Agricultural Economics \\ Faculty of Agricultural Sciences, \\ Ladoke Akintola University of Technology, \\ PMB 4000, Ogbomoso, Oyo State, Nigeria. \\ Lukman, A. F. \\ Department of Physical Sciences, \\ Landmark University, Omu-Aran, Kwara \\ State, Nigeria \\ T. O. Olawuyi \\ Research Outreach Department, \\ National Cereals Research Institute, \\ P.M.B 8, Badeggi. Niger State.
}

\begin{abstract}
Economic growth and development is the main objective of the Nigeria economy. However, variations due to shock or innovation in different economic variables reveal volumes to the policy makers and economists. The primary objective of the paper is to examine the relationships between agricultural export and economic growth in Nigeria employing the vector autoregressive (VAR) impulse response function analysis technique. Nigeria's annual time series data on economic growth (proxied as real gross domestic product), gross domestic capital formation, real exchange rate, and agricultural exports to other countries were employed in the study. The data which spanned the period of 1980 to 2015 were sourced from FAOSTAT database of the Food and Agricultural Organization of the United Nations, Central Bank of Nigeria online Statistical database and the World Bank. Results show that agricultural export has a positive and significant effect on economic growth in Nigeria. The influence of the shock or innovation of agricultural export to economic growth is almost doubled in the long run as compared to that of short run. The shock of real effective exchange rate on economic growth in the long run is far stronger than the innovation in the short run. It will therefore be a suitable measure to increase agricultural export and real exchange rate to accelerate the economic growth of the nation in the long run.
\end{abstract}

Keywords: Economic growth, Impulse Response, Agricultural Export, Variance Decomposition, Vector Autoregressive

\section{INTRODUCTION}

Before the discovery and consequent boom of crude oil in the 1970s, agricultural export was the mainstay of the Nigerian economy. The contribution of agricultural exports (cocoa, rubber, palm oil, palm kernel, cotton, etc.) however fell to $35 \%$ of the GDP from an average of $72 \%$ between 1955 and 1969 due to Nigeria's over reliance on the oil sector (Abiodun and Solomon, 2010) [1]. Agriculture indeed had a place of pride in the Nigerian economy then such that Nigeria was ranked very high in the production and exportation of some major crops in the world in the 1940 and 1950s (Ekpo and Egwaikhide,1994) [2]. Abolagba, et al (2010) [3] indicated that agriculture has been the most important single activity in the Nigerian economy with about $70 \%$ of the total working population engaged in that sector before the discovery of crude oil. However, according to Daramola, et al (2007) [4], the contribution of the agricultural sector, which is presently the second largest sector after the oil sector, have fallen over the years from 48 percent of the national GDP in 1970 to 20.6 percent in 1980 and was only 23.3 percent of GDP in 2005. According to him, agricultural exports only represented about 0.2 percent of total exports in 2005 in Nigeria. 


\section{International Journal of Engineering Applied Sciences and Technology, 2019 \\ Vol. 4, Issue 5, ISSN No. 2455-2143, Pages 339-348 \\ Published Online September 2019 in IJEAST (http://www.ijeast.com)}

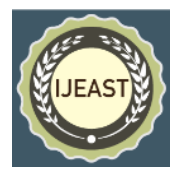

Exportation is required by any economy to enhance revenue and usher in economic growth and development. It is therefore crucial for economic progress and this has informed the idea of export-led growth. Export is a catalyst necessary for the overall development of an economy (Abou-Strait, 2005) [5]. It was also noted that foreign trade creates an avenue for foreign capital to flow into a country. This increases the earnings of the country thereby creating an avenue for growth by raising the national income of the country. It also increases the level of employment in the economy as a higher demand for exports will require more production which will in turn lead to the employment of more people. Exportation by a country also helps attain a favourable balance of trade and balance of payment position for the exporting country provided its exports reasonably exceed its imports.

According to Verter and Bečvařova (2016) [6], there is a longstanding debate over the relationship between the export and economic growth in both advanced and less advanced economies. There are a couple of empirical studies that confirm the robust connection between export and economic growth in countries across the globe. Some studies support the hypothesis of export-led growth (ELG) mostly in the developing nations (Kavoussi, 1984[7]; Ram, 1985[8]; Shirazi and Manap, 2005[9]]). They argue that the exports of goods and services generate foreign exchange that is required to import foreign goods. The increase in underlying commodities' imports, in turn, stimulates a nation's capacity to produce in the long run. This is more pronounced in less developed economies that have a heavy disadvantage in the production of capital goods (Verter and Bečvařova, 2016) [6].

Until recently, scholars had paid little attention to general phenomena ELG and limited works have being initiated so far to study the linkage between economic growth and agricultural exports. Given that ELG hypothesis has been confirmed in countries, it is worthwhile to determine if agricultural export led- economic growth hypothesis also holds. Economists, world organizations and scientist believe that agricultural export is a catalyst for growth, especially in developing countries where it is the main source of foreign earnings and national incomes (Verter and Bečvařova, 2014[6]; Verter, 2015[10]). They also have some arguments in support of trade in food and agriculture. International trade brings the total amount of goods and services to the countries involved. It also brings the diversity of commodities that increase choices to the populace. To some extent, trade maintains stable demand and supply that allows efficient exchanges and stimulate economic growth and development in countries (Erokhin, Ivolga and Heijman, 2014[11]; Verter and Bečvařova, 2014 [6]). Nevertheless, agricultural exports can accelerate a balanced growth in all countries involved if only issues (trade restrictions and distortions) related to the world trade in primary agricultural trade are addressed or drastically reduced (Anderson and Martin, 2005[12]; McCally and Nash, 2007[13]; Laborde and Martin, 2012[14]; Verter, 2015[10]).

In Nigeria, the accrued earnings from agricultural export brought numerous benefits to the country and the continent at large. The government revenue depended heavily on agricultural export taxes and both the current account and fiscal balances depended to some extent on agriculture before the discovery of oil (Folawewo and Olakojo, 2010) [15]. However, since the oil-boom era of the 1970s, the contributions of agriculture to foreign earnings have remained abysmally low, representing less than 1 percent between 2000 and 2004 (Central Bank of Nigeria, 2005) [16]. Although, agriculture is still the leading earner of foreign exchange from non-petroleum exports, the reduction in agricultural activities has caused a high level reduction in local food production, making Nigeria one of the leading nations in importation of food to supplement local production, which has inadvertently led to growing importation and falling export earnings (Nwachukwu, et al, 2008) [17].

However, owing to the recent dramatic increase in oil production globally and especially in the USA, formerly, Nigeria's highest oil export destination, and the recent discovery and production of petroleum in other countries like Israel, Ghana and Tanzania, coupled with persistent dwindling price of oil in the world market, the demand for the Nigeria's oil has been threatened. In other words, it is not unexpected that Nigeria's economy is vulnerable to the global oil price shocks (Osakwe, Verter and Darkwah, 2015) [18]. One of the consequences was that the country's economy entered into a period of recession lately. It is therefore apparent that for Nigeria to survive as a nation now or the near future, economic diversification is inevitable. In the light of this, economists have called for export diversification by promoting and stimulating other sectors such as agricultural commodities sector of the economy for maximum domestic production and exports (Verter and Bečvařova, 2014) [6]. The question to ask then is does global trade in agriculture support the agricultural export- led economic growth hypothesis in Nigeria? Empirical results so far obtained elsewhere have remained mixed, inconclusive or rather contradictory, thus, the relevance of this present study for Nigeria. The primary focus of this article therefore is to determine if agricultural export- led economic growth hypothesis holds in Nigeria.

\section{MethodOLOGY}

\subsection{Data Source and Measurement}

To examine the effect of agricultural export on economic growth in Nigeria, annual time series data covering the period between 1980 and 2015 for the analysis were obtained from Central Bank of Nigeria Statistical Bulletin, FAOSTAT data base and World Bank. Furthermore, all of the series are 


\section{International Journal of Engineering Applied Sciences and Technology, 2019 \\ Vol. 4, Issue 5, ISSN No. 2455-2143, Pages 339-348 \\ Published Online September 2019 in IJEAST (http://www.ijeast.com)}

transformed into natural logarithm form. These series are not deterministic variables. They share some stochastic properties. Charles. Nelson and Plosser (1982) [19] hold that macroeconomic time series usually behave like random walks. These series are not 'trend reverting'

In other to determine if agricultural exports- led economic growth hypothesis holds in Nigeria, real gross domestic product growth (RGDPG) is captured as a function of the agricultural exports, the agricultural degree of openness, gross capital formation and real exchange rate. All the data in the models were run using E-Views 10 econometric software. The model is specified as follows:

\section{$L R G D P G=f(L E R, L A E X P V, L G C F, L A D O P)$}

this is also stated as:

$L R G D P G=a+b L E R+c L A E X P V+d L G C F+e L A D O P+\varepsilon$

where RGDPG denotes the Real Gross Domestic Product Growth which is the proxy for economic growth in this study. $L A E X P V$ stands for the agricultural export value, $L A D O P$ is the agricultural degree of openness which is calculated as [(agricultural export + agricultural import)/ nominal GDP]. It can also be referred to as agricultural trade-to-GDP ratio or agricultural trade openness ratio, which is a measure for the integration of agricultural trade into the global economy. $L G C F$ is the Gross Capital Formation for Nigeria while $L E R$ is the Real Exchange Rate. An increase in $L E R$ implies that exports become more lucrative than imports. Finally, $\varepsilon$ represents the error term. A priori, all the explanatory variables in the model are expected to have positive impacts on economic growth.

\subsection{Analytical Techniques}

\subsubsection{Vector Autoregressive Model}

This study applied the Augmented Dickey Fuller unit root test to examine the unit root properties of the data series before proceeding on the VAR analysis. This is particularly necessary to avoid reporting spurious regressions. The test determines whether the seriesis stationary at the level, first or second difference. A VAR model is merely used to examine the dynamic relationship between economic growths and selected macroeconomic variables. The VAR model is particularly important because the variables are treated symmetrically in a structural sense and may be viewed as a system of reduced form equations in which each of the endogenous variables is regressed on its own lagged values and the legged values of all other variables in the system (Gujarati, 2004) [20]. Following the methods and procedures in Reinsel and Sung (1992) [21] and Lütkepohl (2005) [22], the basic form of a VAR model consists of a set of $\mathrm{K}$ economic indicator variables.

$$
Y_{t}=\left(Y_{1 t}, Y_{2 t}, \ldots, Y_{k t}\right)
$$

observed at time $t=0,1,2, \ldots$, and defined with order $p$ as

$$
Y_{t}=\omega+A_{1} Y_{t-1}+A_{2} Y_{t-2}+\ldots .+A_{p} Y_{t-p}+u t
$$

and $A_{i}$ is $(K \times K)$ coefficient matrix for each $i=1,2, \ldots, \mathrm{n}$. The necessary assumptions considered under model (1) are stationarity, $u_{t}$ is a $K$-dimensional white noise process with $E\left(u_{t}\right)=0, \omega=\left(\omega_{1}, \omega_{2}, \ldots, \omega_{k}\right)^{\prime}$ is a fixed $(K \times 1)$ vector of intercept terms allowing for the possibility of a non-zero mean, $E\left(Y_{t}\right)$, and $u_{t}$ is time invariant with positive definite covariance matrix.

This study employed multivariate vector autoregressive (VAR) model to identify the current effect and the short term relationship between economic growth and agricultural export and other economic growth indicator variables. VAR model estimation is usually applied to examine the dynamic relationships between two (or more) time series variables. According to Gudeta et al (2017) [23], the model involves only predetermined variables as predictors, thus avoiding specification of endogenous dependence.

The descriptions of the models and approaches used by Gudeta et al (2017) [23] and which this study also adapted is presented further.

\section{Selection of Lag Length for the VAR Estimation}

In the time series estimation of any VAR model, the selection of maximum lag length $(\mathrm{k})$ is important. This is because the inclusion of too many lagged terms will consume degrees of freedom and consequently, problem of multi-collinearity may arise. On the other hand, inclusion of few lags may lead to selection errors.

\section{Determining the VAR Order}

The most popular method to choose the lag order $p$ is to use information criteria. An information criterion is designed to consistently find the model that fits better the data from a group of models. The decision about how many lag order to be included in the regression depends upon the model selection criterion, that is determined by minimizing the Schwartz Bayesian Information Criterion (BIC) or minimizing the Akaike Information Criterion (AIC) or lags are dropped until the last lag is statistically significant.

The Schwartz Bayesian Information Criterion (BIC) and the Akaike Information Criterion (AIC) are the common criteria used to choose the VAR order $p$. Each one may choose different models. The SIC (Schwarz IC or Bayesian IC) generally chooses models with a smaller $p$ while AIC (Akaike) chooses models with a higher order $p$. 


\section{International Journal of Engineering Applied Sciences and Technology, 2019 \\ Vol. 4, Issue 5, ISSN No. 2455-2143, Pages 339-348 \\ Published Online September 2019 in IJEAST (http://www.ijeast.com)}

\subsubsection{Impulse Response Function}

The impulse response test shows the effects of an exogenous shock on the whole process over time. The idea is initially to look at the adjustment of the endogenous variables and to detect the dynamic relationships among contemporaneous values of the variables over time, after a hypothetical shock in time t. This adjustment is compared with the time series process without a shock, i.e. the actual process. The impulse response sequences plot the difference between this two time paths which offers additional arguments for adjusting its appearance. The Wolds moving average decomposition for stable $\operatorname{VAR}(\mathrm{p})$-process which is defined as:

$$
Y_{t}=\Phi_{0} u_{t}+\Phi_{1} Y_{t-1}+\Phi_{2} Y_{t-2}+\ldots
$$

with $\Phi_{0}=I_{k}$ and $\Phi_{s}=\sum_{j=o}^{s} \Phi_{s-j} A_{j}, s=1$,

$2,3, \ldots$

Thus, it is possible to pre-occupy the effect of a non-recurring shock in one variable, to all variables over time. The positive definite symmetric matrix $\Sigma_{u}$ can be written as the product $\Sigma_{u}=P P^{\prime}$, where $P$ is a lower triangular nonsingular matrix with positive diagonal elements. Thus, one could summarize the result in any covariance stationary VAR(p) process as a Wolds representation by using the method of Ender (1995) [24] of the form:

$$
Y_{t}=\mu+\Sigma_{k=0}^{\infty} \Theta_{k} \mu_{t-k}
$$

where $\Theta_{k}=\Phi_{k} P$ and $\mu_{t-k}=P^{-1} u_{t-k}$ is white noise with covariance matrix

$$
\Sigma_{\mu}=P^{-1} \Sigma_{u}\left(P^{-1}\right)^{\prime}=I_{k}
$$

with, $\Phi_{k}=I_{k}$ is a vector moving average process and $\Phi_{k}$ are the weight of past shocks are determined recursively using

$$
\phi_{k}=\sum_{j=1}^{p-1} \phi_{k-j} A_{j}
$$

where $\phi_{k}=I_{k}$ and $A_{j}=0$ for $j>p$ as in equation (1) of $\operatorname{VAR}(\mathrm{p})$ model specification.

Once a recursive ordering has been established, the Wolds representation of $Y_{t}$ based on the orthogonal errors $\eta_{t}$ is given as shown in (5) by:

$$
Y_{t}=\mu+\sum_{k=0}^{\infty} \Theta_{k} \eta_{t-k}
$$

$\Theta_{0}=B^{-1}$ is a lower triangular matrix. The impulse responses to the orthogonal shocks $\eta_{i t}$ are

$$
\frac{\partial Y_{i, t+s}}{\partial \eta_{j, t}}=\frac{\partial Y_{i, t}}{\partial \eta_{j, t-s}}=\theta_{i j}^{s}, i, j=1, \ldots ., n ; s>0
$$

Where, $\theta_{i j}^{s}$ is the $(i, j)^{\text {th }}$ term of $\Theta_{s}$.

A plot of $\theta_{i j}^{s}$ against $s$ is called the orthogonal impulse response function (IRF) of $Y_{i}$ with respect to $\eta_{j}$. With $n$ variables there are $n^{2}$ possible impulse response functions.

\section{Variance Decomposition}

An alternative of impulse responses, to receive a compact overview of the dynamic structures of VAR models, are variance decomposition sequences. The VDCs show the portion of the variance in the forecast error for each variable due to innovations to all variables in the system (Enders, 1995) [24]. This method is also based on a vector moving average model and orthogonal error terms. In contrast to impulse response, the task of variance decomposition is to achieve information about the forecast ability. The idea is that even a perfect model involves ambiguity about the realization of $Y_{i, t}$ because of uncertainty in the error terms association. According to the interactions between the equations, the uncertainty is transformed to all equations. The aim of VDC is to reduce the uncertainty in one equation to the variance of error terms in all equations.

The forecast error variance decomposition is based upon the orthogonalised impulse response coefficient matrices $\Phi_{k}$ and allow the user to analyze the contribution of variable $j$ to the $h$-step forecast error variance of variable $i$. If the orthogonalised impulse responses are divided by the variance of the forecast error $\sigma_{k}^{2}(h)$, the resultant is a percentage figure. Formally:

$$
\sigma_{k}^{2}(h)=\sum_{j=0}^{K}\left(\Phi_{k j, n}^{2}+\ldots+\Phi_{k j, n}^{2}\right)
$$

Dividing the term $\left(\Phi_{k j, n}^{2}+\ldots+\Phi_{k j, n}^{2}\right)$ by $\sigma_{k}^{2}(h)$ yields the forecast error variance decompositions in percentage terms. 


\section{International Journal of Engineering Applied Sciences and Technology, 2019 \\ Vol. 4, Issue 5, ISSN No. 2455-2143, Pages 339-348 \\ Published Online September 2019 in IJEAST (http://www.ijeast.com)}

\section{RESULTS AND DISCUSSION}

\subsection{Results of Unit Root tests}

The need for the test of time series data is very essential knowing the fact that time series data is prone to spurious regression results (Granger and Newbold, 1974) [25]. In order to examine the unit root properties of the variables employed in this study, the ADF (Augmented Dickey Fuller) unit root test was employed. The findings of the stationary test are presented in Table 1 below. The test result shows that all the variables have unit root properties. They also became stationary after first differencing. Given that all the variables in the model have order of integration of 1 that is $\mathrm{I}(0)$, other analysis are thereafter carried out. These are the Autoregressive Distributed Lag (ARDL) regression to examine the relationship between agricultural export and economic growth, Impulse Response function and the Variance Decomposition Analysis (VDA).

Table 1: Results of Unit Root tests

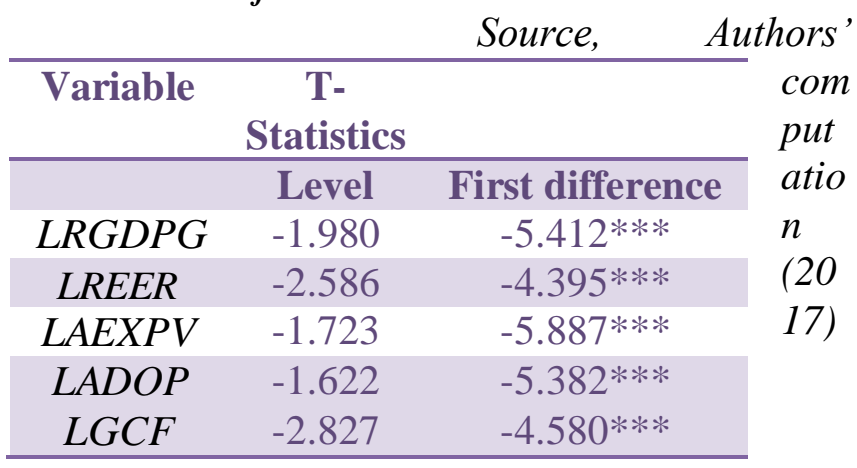

Source, Authors' computation (2017)

$N B: * * *$ denotes statistical significance at 0.01 level.

\subsection{Relationship between Economic Growth and Agricultural Export in Nigeria}

The estimated ARDL model fitted to examine the relationship between agricultural export and economic growth in Nigeria passes a battery of diagnostic tests. The graphical evidence (CUSUM and CUSUMQ graphs) also indicate that the model is fairly stable during the sample period. The analysis of the stability of the long-run coefficients together with the shortrun dynamics, the cumulative sum (CUSUM) and the cumulative sum of squares (CUSUM) point to the in-samples stability of the model (see CUSUM and CUSUMQ in Figures 1 and 2).
The Autoregressive Conditional Hetoroscedasticity (ARCH) test for testing heterscedasticity in the error process in the model has an F-statistic of 0.435 , which is statistically insignificant. This shows that there is the absence of heteroscedasticity in the model. The Breusch - Godfrey Serial correlation Langrange Multiplier (LM) test for higher order serial correlation with a calculated $\mathrm{F}$ - statistic of 0.285 confirms the absence of serial correlation in the residuals. The Jargue - Bera Normality test on the residuals also shows that the error process is normally distributed. From the battery of diagnostic tests presented and discussed above, this study concludes that the model is well estimated and that the observed data fits the model specification adequately, thus the residuals are expected to be distributed as white noise and the coefficient valid for policy discussions.

Figure 1: Cusum test results

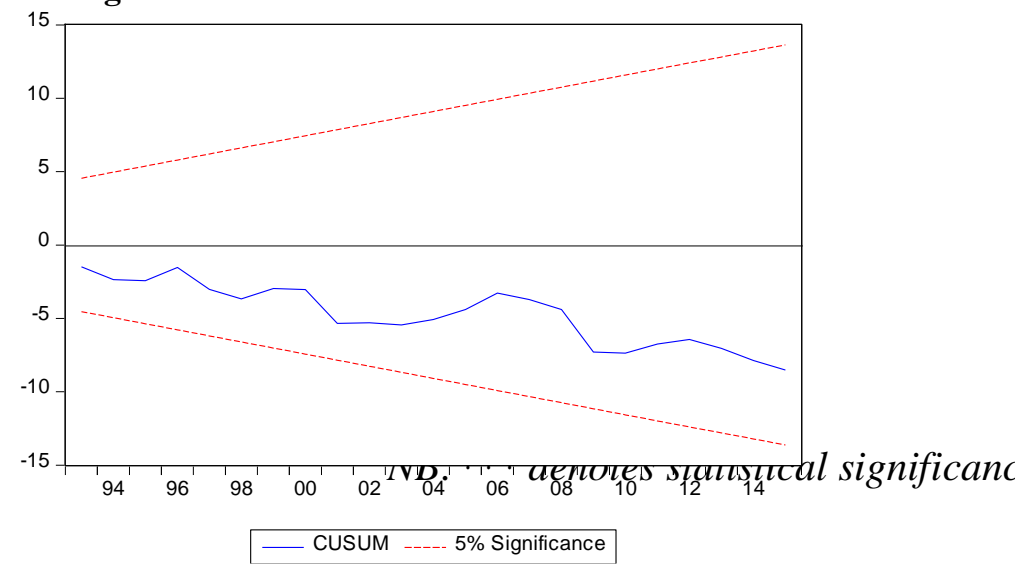

Figure 2: Cusum of Squares test results

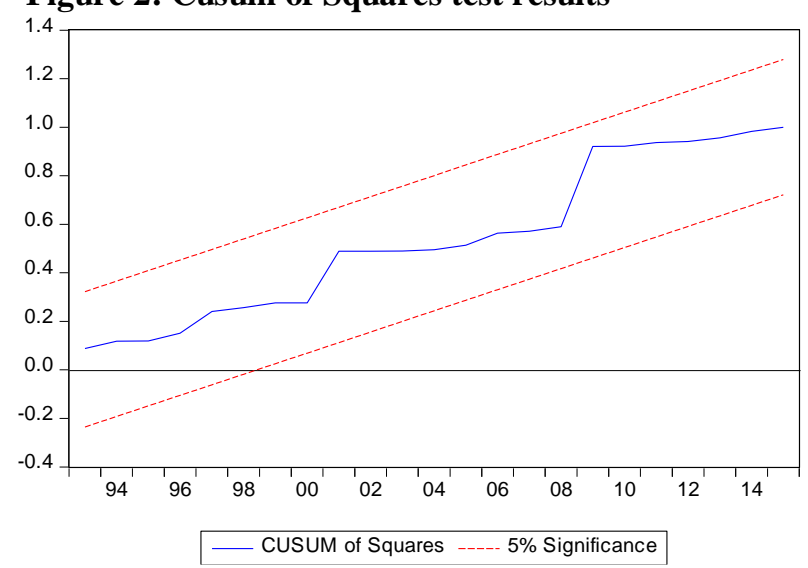

Table 2: Breusch-Godfrey Serial Correlation LM Test Null hypothesis: No serial correlation at up to 2 lags

\begin{tabular}{|l|l|l|}
\hline F-statistic & 0.285097 & Prob. F(2,21) 0.7548 \\
\hline $\begin{array}{l}\text { Obs*R- } \\
\text { squared }\end{array}$ & 0.845899 & Prob. Chi-Square (2) 0.6551 \\
\hline
\end{tabular}




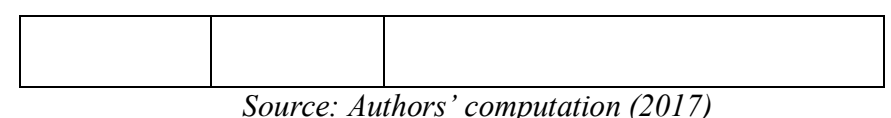

Source: Authors' computation (2017)

Table 3: Breusch-Pagan-Godfrey Heteroskedasticity Test Null hypothesis: Homoskedasticity

\begin{tabular}{|l|l|}
\hline $\begin{array}{l}\text { F-statistic } \\
0.434\end{array}$ & Prob. F(8,23) 0.8878 \\
\hline Obs*R-square 0.845 & Prob. Chi-Square (2) 0.838 \\
& \\
\hline Scaled explained SS 2.599 & Prob. Chi-Square(8) 0.956 \\
& \\
\hline
\end{tabular}

Source: Authors' computation (2017)

Figure 3: Jarque Bera Normality test

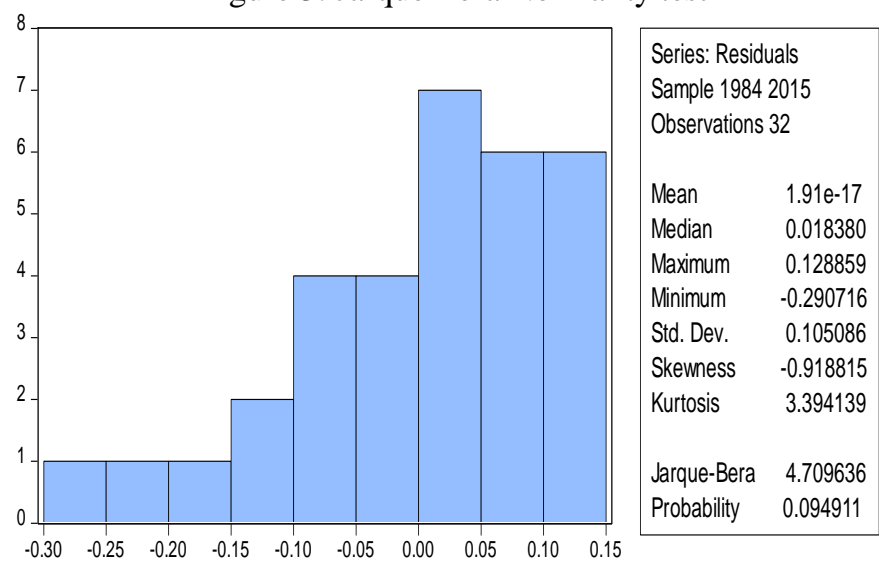

As presented in Table 4, the ARDL estimation results suggest a negative relationship between the Real Gross Domestic product (which is proxy for economic growth) in the previous year $\left(L R G D P G_{t-1}\right)$ and the Real Gross Domestic Product $L R G D P G$ in Nigeria, statistically not significant at any level. It implies that ceteris paribus, a unit increase in the $L R G D P G_{t-1}$ will bring no significant effect to the real gross domestic product $L R G D P G$ in the present year.

Gross Capital Formation ( $L G C F)$ has a positive effect on economic growth ( $L R G D P G)$ in Nigeria. The coefficient is significant at 1 percent level. It implies that all things being equal, 1 percent unit increase in $L G C F$ will bring about 44.6 percent increases in economic growth ( $L R G D P G)$. In the same fashion, the result further indicate that the Agricultural Degree of Trade openness has a negative effect the economic growth and it is statistically significant at 1 percent level. This suggests that a 1 percent increase in the degree of openness of agricultural trade in Nigeria $(L A D O P)$ may cause a strategic reduction in economic growth by 61 percent in the country. On the hand, the degree of openness in the previous period (i.e. the year before) also has a negative effect on economic growth in Nigeria. The coefficient is -0.621 and it is also significant statistically. This result though is contrary to a priori expectation; it is in line with the works of Anowor, Ukweni and Martins (2013) [26] who also find a negative relationship between agricultural trade openness and economic growth in Nigeria. This result corroborates the findings of Verter and Becvarova (2016) [27] and it is also not surprising as Nigeria has been recording negative trade balance in agricultural products since 1975 . The consequence of this has been the massive import of agricultural commodities which has negatively affected Nigeria's economic growth over time.

Real Exchange Rate ( $L E R)$ has a positive and significant coefficient of 0.11 . This suggests that it will stimulate about 11 percent increase in the nation's economic growth. This result is in line with the work of Verter and Becvarova (2016) [27] but contradicts the findings of Ojide, et al (2014)[28] who find an inverse relationship between exchange rate and economic growth in Nigeria.

Agricultural Export Value lagged two years has a positive and significant coefficient of 0.306 and is significant at $5 \%$. This results aligns with the findings of Shombe (2008) [29]; Bbaale and Mutenyo (2011) [30]; Ojo et al (2014) [31]; Shirazi and Manap (2005) [9] also confirm a positive relationship between agricultural exports and economic growth in Nigeria

Table 4: Autoregressive Distributed Lags Estimation of Agricultural Export and Economic Growth in Nigeria Selected Model: ARDL $(\mathbf{1 , 0 , 1 , 0 , 2 )}$

\begin{tabular}{lcc}
\hline \multicolumn{1}{c}{ Variable } & Coefficient & t-statistic \\
\hline$D($ LRGDPG(-1)) & $0.005(0.974)$ & 0.033 \\
$D(L G C F)$ & $0.447(0.000)$ & $5.064 * * *$ \\
$D(L A D O P)$ & $-0.611(0.003)$ & $-3.368^{* * *}$ \\
$D($ LADOP $(-1))$ & $-0.622(0.001)$ & $-3.747^{* * *}$ \\
$D($ LREER $)$ & $0.112(0.099)$ & $1.721^{*}$ \\
$D($ LAEXPV $)$ & $0.197(0.166)$ & 1.429 \\
$D($ LAEXPV $(-1))$ & $0.002(0.986)$ & 0.018 \\
$D($ LAEXPV $(-2))$ & $0.306(0.016)$ & $2.588^{* *}$ \\
$C$ & $0.130(0.005)$ & 3.121 \\
R-squared: $\mathbf{0 . 7 0 5}$ & & $\mathbf{F -}$ \\
Adjusted R-squared :0.602 & $\underline{\mathbf{6 . 8 6 2 4 8 0}}$ \\
\hline
\end{tabular}

Source: Authors' computation (2017) 


\section{International Journal of Engineering Applied Sciences and Technology, 2019 \\ Vol. 4, Issue 5, ISSN No. 2455-2143, Pages 339-348 \\ Published Online September 2019 in IJEAST (http://www.ijeast.com)}

Note: Probabilities values in parenthesis

*** indicates significance at $1 \%$

** indicates significance at $5 \%$

* indicates significance at $10 \%$

\subsection{Impulse Response Function Analysis}

An Impulse Response Function (IRF) was further run to reveal the connection between the variables in the model. The IRF model may show the response of a particular variable to a shock or an impulse in another variable in the system that involves some other variables as well because GrangerCausality may not reveal the complete story about the connection between variables in the model. The result of the IRF analysis for this study is presented in Figure 5.

The initial response of real effective exchange rate ( $L R E E R$ ) to economic growth ( $L R G D P G$ ) is negative and then increase drastically above the equilibrium point in the third year and then swiftly decreases to reach a zero (0) level at the fourth year. The response fluctuates over the years as it records adverse shock with the response in the fourth year and the fifth year.

The impulse response of agricultural export volume to economic growth was positive. It however diminished steadily in the second year and it also decreases steeply below equilibrium in the $3^{\text {rd }}$ year. It swiftly increases to reach a plausible direction in the fourth year. The impulse response undulate over the years as it records inauspicious shocks in the third and sixth year.

A perfunctory examination of impulse response of gross capital formation to the economic growth records negative from the first year to the fourth and in the sixth to the eight year. It records positive in the fourth year towards the sixth and eight year but it's fleetly movement as time passes on. Likewise the response from the agricultural degree of openness to economic growth also witnessed negative and positive shock as years passes on. $L A D O P$ raise the economic growth rate for the third year, but also fluctuates reaching below and above the equilibrium levels over the period.

\subsection{Results of Variance Decomposition Analysis}

Statistically speaking, while impulse response function (IRF) traces the effects of a change to another endogenous variable in the VAR environment, Variance Decomposition Analysis (VDA) separates the variations in an endogenous variable into the component shocks in the model. Thus, the variance decomposition analysis provides information about the relative relevance of each of the random innovations affecting the variables in the VAR model.
The variance decomposition analysis results for the selected variables ( $R G D P G, R E E R, A E X P V, G C F, A D O P$ ) over a 10 year horizon are presented in Tables $5 \mathrm{~A}$ to $5 \mathrm{~B}$. The results divulge that economic growth ( $R G D P G$ ) variable was 100 percent explained by its shock in the first year, but it slowly reduces to 86 percent in the long-run (i.e. the $10^{\text {th }}$ year). Other complementary results show that real exchange rate have 1 percent, the Agricultural Export Volume has a total of 6 percent, Gross Capital formation (3 percent) and lastly the Agricultural Degree of Openness have 4 percent report for the fluctuations in the economic growth in the long-run (i.e. the $10^{\text {th }}$ year).

However, the findings further confirms that the VDA of Real effective exchange rate gives 97 percent, explained by its shock in the first year but steadily reduces to 68 percent in the long-run (i.e. the $10^{\text {th }}$ year), other variables $R G D P G, A E X P V, G C F$ and $A D O P$ shares 23 percent, 3 percent , 3 percent and 3 percent respectively in the longrun. Furthermore the VDA of Agricultural Export Volume also was 83 percent in the first year but gradually reduce to 72.6 percent in the long-run while other variables ha 14.4 percent, 9.2 percent, 1.6 percent and 2.2 percent for $R G D P G, R E E R, G C F$ and $A D O P$ respectively, lastly the VDA of $G C F$ and $A D O P$ at the long-run reflects a percentage share of 52.4 percent and 46 percent respectively.
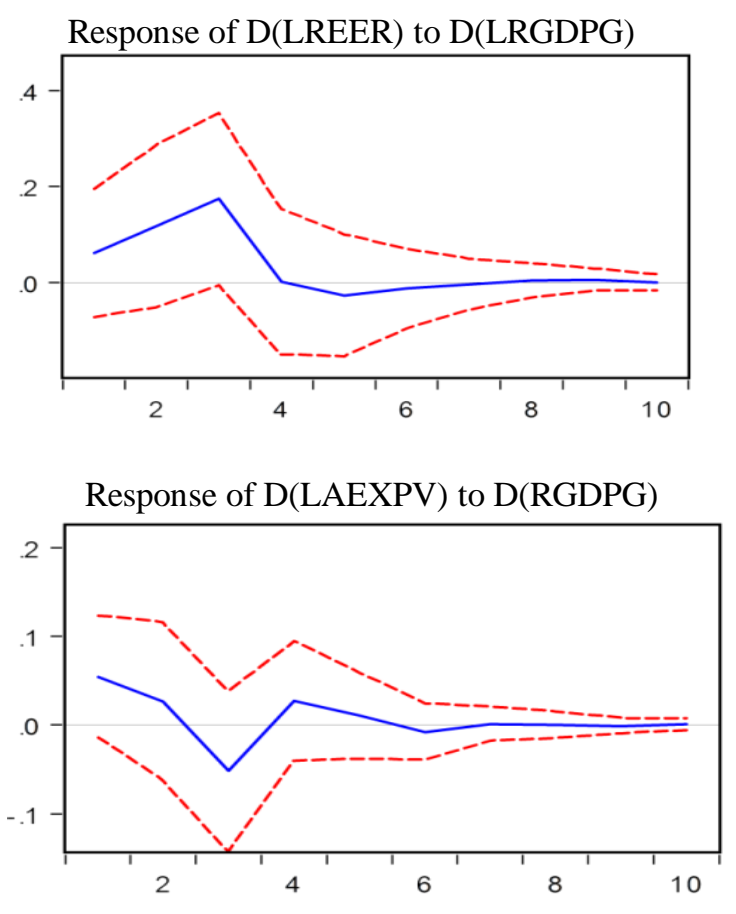


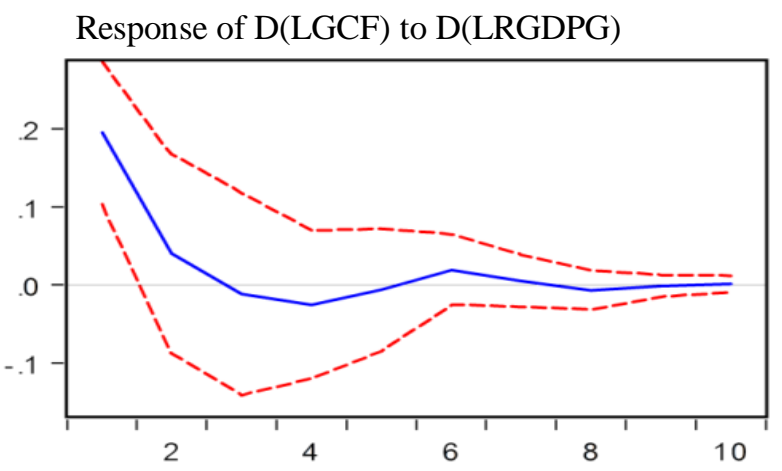

Response of D(LADOP) to D(LRGDPG)

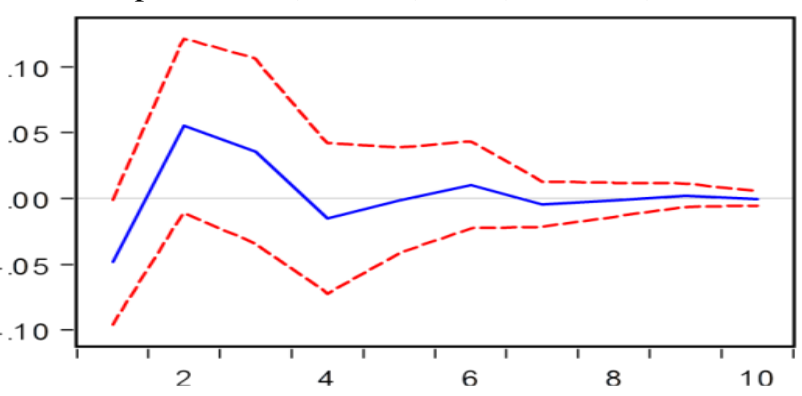

Response of D(LRGDPG) to D(LREER)

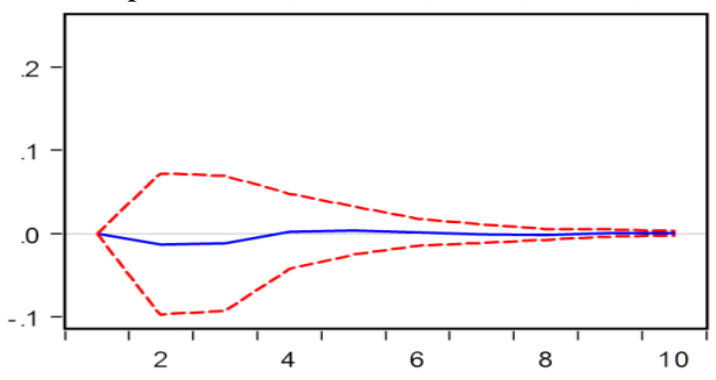

Response of D(LRGDPG) to D(LAEXPV)

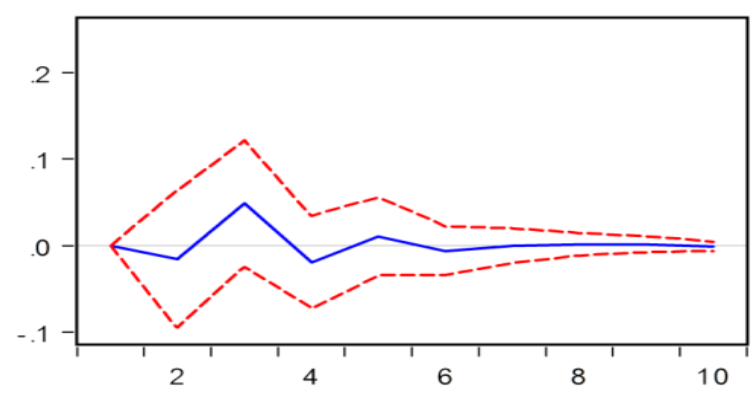

Response D(LRGDPG) to D(LGCF)

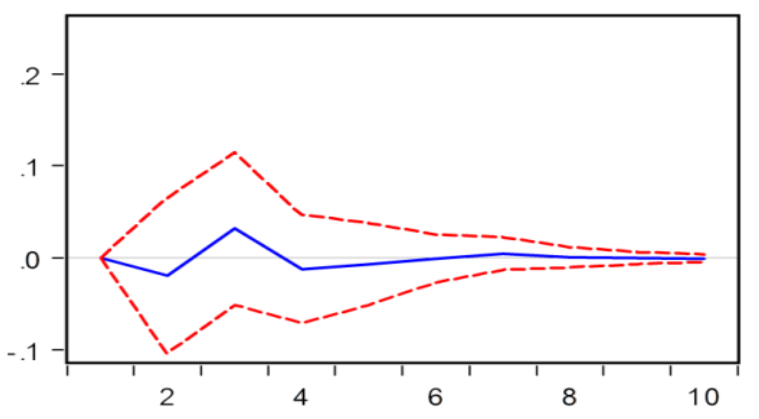

Response D(LRGDPG) to D(LADOP

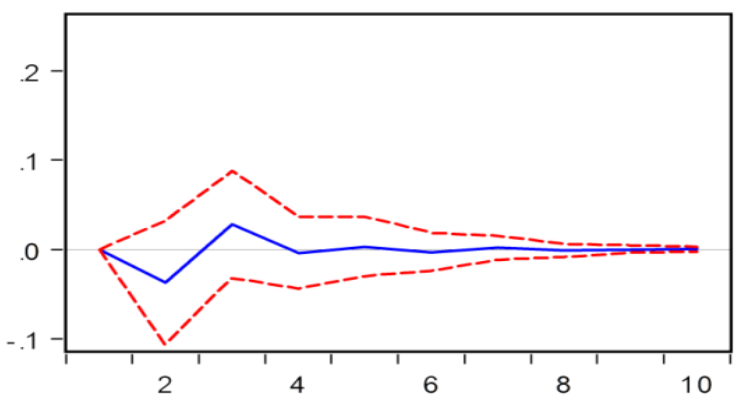

Figure 4: Response to Cholesky One S. D. (d. f. adjusted) innovation S. E.

Table 5: Variance Decomposition Analysis

Table 5A: Variance Decomposition Analysis of $D(L R G D P G)$

\begin{tabular}{lrlllll}
\hline Period & S.E. & $D($ LRGDPG $)$ & $D($ LREER $)$ & $D(L A E X P V)$ & $D(L G C F)$ & $D(L A D O P)$ \\
\hline $\mathbf{1}$ & 0.210 & 100.000 & 0.000 & 0.000 & 0.000 & 0.000 \\
$\mathbf{2}$ & 0.217 & 95.402 & 0.356 & 0.513 & 0.782 & 2.946 \\
$\mathbf{3}$ & 0.227 & 87.549 & 0.604 & 5.024 & 2.647 & 4.176 \\
$\mathbf{4}$ & 0.229 & 86.621 & 0.607 & 5.699 & 2.915 & 4.158 \\
$\mathbf{5}$ & 0.229 & 86.317 & 0.627 & 5.889 & 3.006 & 4.161 \\
$\mathbf{6}$ & 0.229 & 86.244 & 0.630 & 5.951 & 3.003 & 4.172 \\
$\mathbf{7}$ & 0.229 & 86.226 & 0.630 & 5.948 & 3.040 & 4.176 \\
$\mathbf{8}$ & 0.229 & 86.198 & 0.634 & 5.950 & 3.040 & 4.178 \\
$\mathbf{9}$ & 0.229 & 86.195 & 0.634 & 5.953 & 3.040 & 4.178 \\
$\mathbf{1 0}$ & 0.229 & 86.193 & 0.635 & 5.954 & 3.041 & 4.178 \\
\hline
\end{tabular}

\begin{tabular}{|c|c|c|c|c|c|c|}
\hline Period & S.E. & $D(L R G D P G)$ & $D(L R E E R)$ & $D(L A E X P V)$ & $D(L G C F)$ & $D(L A D O P)$ \\
\hline 1 & 0.382 & 2.565 & 97.435 & 0.000 & 0.000 & 0.000 \\
\hline 2 & 0.409 & 10.479 & 86.686 & 1.694 & 0.949 & 0.191 \\
\hline 3 & 0.454 & 23.295 & 70.514 & 2.373 & 0.873 & 2.945 \\
\hline 4 & 0.460 & 22.660 & 68.939 & 2.645 & 2.813 & 2.943 \\
\hline 5 & 0.462 & 22.894 & 68.640 & 2.723 & 2.797 & 2.945 \\
\hline 6 & 0.462 & 22.877 & 68.388 & 2.740 & 3.060 & 2.934 \\
\hline 7 & 0.463 & 22.856 & 68.334 & 2.789 & 3.090 & 2.931 \\
\hline
\end{tabular}




\begin{tabular}{ccccccc}
\hline $\mathbf{8}$ & 0.463 & 22.855 & 68.311 & 2.797 & 3.107 & 2.930 \\
$\mathbf{9}$ & 0.463 & 22.862 & 68.291 & 2.798 & 3.117 & 2.931 \\
$\mathbf{1 0}$ & 0.463 & 22.862 & 68.290 & 2.800 & 3.117 & 2.931 \\
\hline
\end{tabular}

Table 5C: Variance Decomposition Analysis of $D(L A E X P V)$

\begin{tabular}{ccccccc}
\hline Period & S.E. & $D($ LRGDPG $)$ & $D($ LREER $)$ & $D($ LAEXPV $)$ & $D(L G C F)$ & $D($ LADOP $)$ \\
\hline $\mathbf{1}$ & 0.198 & 7.585 & 9.511 & 82.904 & 0.000 & 0.000 \\
$\mathbf{2}$ & 0.214 & 8.017 & 10.088 & 80.290 & 1.520 & 0.085 \\
$\mathbf{3}$ & 0.222 & 12.896 & 9.362 & 74.534 & 1.432 & 1.776 \\
$\mathbf{4}$ & 0.224 & 14.099 & 9.227 & 73.014 & 1.418 & 2.242 \\
$\mathbf{5}$ & 0.225 & 14.266 & 9.205 & 72.723 & 1.568 & 2.237 \\
$\mathbf{6}$ & 0.225 & 14.369 & 9.201 & 72.621 & 1.566 & 2.243 \\
$\mathbf{7}$ & 0.225 & 14.364 & 9.197 & 72.620 & 1.576 & 2.243 \\
$\mathbf{8}$ & 0.225 & 14.362 & 9.199 & 72.619 & 1.576 & 2.243 \\
$\mathbf{9}$ & 0.225 & 14.364 & 9.199 & 72.616 & 1.577 & 2.244 \\
$\mathbf{1 0}$ & 0.225 & 14.365 & 9.199 & 72.614 & 1.577 & 2.245 \\
\hline
\end{tabular}

\begin{tabular}{|c|c|c|c|c|c|c|}
\hline Period & S.E. & $D(L R G D P G)$ & $D(L R E E R)$ & $D(L A E X P V)$ & $D(L G C F)$ & $D(L A D O P)$ \\
\hline 1 & 0.294 & 43.872 & 0.140 & 0.229 & 56.759 & 0.000 \\
\hline 2 & 0.303 & 43.172 & 1.439 & 1.317 & 53.875 & 0.197 \\
\hline 3 & 0.312 & 40.754 & 1.358 & 4.166 & 53.458 & 0.264 \\
\hline 4 & 0.316 & 40.374 & 1.798 & 4.671 & 52.771 & 0.386 \\
\hline 5 & 0.317 & 40.284 & 1.795 & 4.881 & 52.620 & 0.419 \\
\hline 6 & 0.318 & 40.404 & 1.827 & 4.884 & 52.414 & 0.471 \\
\hline 7 & 0.318 & 40.402 & 1.829 & 4.892 & 52.405 & 0.472 \\
\hline 8 & 0.318 & 40.425 & 1.828 & 4.889 & 52.383 & 0.476 \\
\hline 9 & 0.318 & 40.422 & 1.829 & 4.889 & 52.385 & 0.476 \\
\hline 10 & 0.318 & 40.422 & 1.829 & 4.890 & 52.383 & 0.476 \\
\hline
\end{tabular}

\begin{tabular}{|c|c|c|c|c|c|c|}
\hline Period & S.E. & $D(L R G D P G)$ & $D(L R E E R)$ & $D(L A E X P V)$ & $D(L G C F)$ & $D(L A D O P$ \\
\hline 1 & 0.138 & 12.213 & 0.278 & 0.123 & 25.136 & 62.247 \\
\hline 2 & 0.166 & 19.418 & 0.725 & 0.294 & 27.235 & 52.328 \\
\hline 3 & 0.173 & 22.047 & 1.014 & 3.563 & 25.170 & 48.203 \\
\hline 4 & 0.176 & 21.940 & 0.992 & 6.239 & 24.270 & 46.556 \\
\hline 5 & 0.177 & 21.784 & 1.082 & 6.832 & 24.090 & 46.210 \\
\hline 6 & 0.177 & 22.008 & 1.079 & 6.804 & 24.002 & 46.109 \\
\hline 7 & 0.177 & 22.039 & 1.086 & 6.812 & 23.973 & 46.088 \\
\hline 8 & 0.177 & 22.041 & 1.089 & 6.811 & 23.973 & 46.083 \\
\hline 9 & 0.177 & 22.052 & 1.089 & 6.812 & 23.969 & 46.076 \\
\hline 10 & 0.177 & 22.052 & 1.089 & 6.814 & 23.968 & 46.074 \\
\hline
\end{tabular}

Cholesky Ordering: $D(L R G D P G) D(L R E E R) D(L A E X P V) D(L G C F) D(L A D O P)$ Source: Authors' computation (2017)

\section{CONCluSion AND POLICY ReCOMmEndations}

In conclusion, the result show that agricultural export ledeconomic growth hypothesis actually holds in Nigeria. While other findings showed an inverse relationship between Agricultural degree of openness and economic growth performance in Nigeria, this negative result may be due to the unfavorable conditions in the agricultural balance of trade. However, the result go in line with the hypothesis that agricultural export triggers economic growth in Nigeria. For Nigeria to experience favorable balance of trade in the Agricultural Sector, the locally agro-processing sector should be encouraged, while over reliance on the importation of most agricultural produce that can be produced locally should be discouraged as they may well be harmful to economic growth of the country. This will increase the rate of agricultural production in the country for self-sufficiency, exportation of the agro-commodities and economic growth of the country at large.

\section{REFERENCES}

[1] O.F.Abiodun, O. F. and Solomon, A.O. (2010). Determinants of agricultural exports in oil producing economy: Empirical evidence from Nigeria: Journal of Economic Theory, 4(4)

[2] A. Ekpo and F., Egwaikhide (1994). "Exports and Economic growth in Nigeria: A Reconsideration of the evidence", Journal of Economic Management, 1:100-115

[3] E. O. Abolagba,, Onyekwere, N. C., Agbonkpolor, B. N. and H. Y. Umar (2010). Determinants of Agricultural Exports. J.Hum. Ecol. 27 (3): 181-184.

[4] A. Daramola, Ehui, S., Ukeje, E., and J. McIntire (2007). Agricultural Export Potential in Nigeria. Economic Policy Options for a Prosperous Nigeria. 1-38.

[5] F. Abou-Strait, (2005). Are Exports The Engine Of Economic Growth? An Application of Cointegration and Causality Analysis for Egypt, 1977-2003. African Development Bank, Economic Research Working Paper.

[6] N. Verter, and V., Bečvařova,. (2014). Analysis of some drivers of cocoa export in Nigeria in the era of trade liberalization. Agris On-Line Papers in Economics and Informatics, 6(4): 208-218

[7] R. M. Kavoussi (1984). Export Expansion and Economic Growth. Journal of Development Economics, 14: 241-50

[8] R. Ram, (1985): Exports and economic growth: Some additional evidence. Economic Development and Cultural Change, 33(2): 415-425 


\section{International Journal of Engineering Applied Sciences and Technology, 2019 \\ Vol. 4, Issue 5, ISSN No. 2455-2143, Pages 339-348 \\ Published Online September 2019 in IJEAST (http://www.ijeast.com)}

[9] N. S. Shirazi, and Manap, A. A. (2005). Export-led growth hypothesis: Further econometric evidence from South Asia. The Developing Economies, 43(4): 472-488

[10] N. Verter, (2015): The application of international trade theories to agriculture. Mediterranean Journal of Social Sciences, 6(6): 209-219.

[11] V. Erokhin, V., Ivolga A. and W., Heijman, W. (2014): Trade liberalization and state support of agriculture: effects for developing countries. Agricultural Economics - Czech, 58(11): 354-366

[12] K. Anderson. and Martin, W. (2005). Agricultural trade reform and the Doha development agenda. World Bank Policy Research Working Paper 3607. Washington, D.C.: World Bank.

[13] A. F. Mccally, And Nash, J. (2007). Reforming agricultural trade for developing countries: Volume one: Key issues for a pro-development outcome of the Doha Round. Washington, D.C.: World Bank

[14] D. Laborde, and Martin, W. (2012). Agricultural trade: what matters in the Doha round? Annual Review of Resource Economics, 4: 265-283.Lutkepohl (1999);

[15] A. O. Folawewo, and A. O. Olakojo (2010). Determinants of Agricultural Exports in oil Exporting Economy. Empirical Evidence of Nigeria. J.Econ. Theory, 4 (4): 84-92

[16] Central Bank of Nigeria (2005). Annual Report and Statement of Account, Abuja

[17] I. N. Nwachukwu, Ehumadu, F. C., Mayeha, R. O., Nwaru, J. C., Agwo, N. M. and J. I. Onwumere (2008). Empirical Assessment of Nigeria's Agricultural Export and Economic welfare. MPRA P.N 12631. Pp.2-38.

[18] C. N. Osakwe, Verter, N. And Darkwah, S. A. (2015). An empirical analysis of the impacts of external capital infl ows and world oil price on Africa's 'largest' market. WSEAS Transactions on Business and Economics, 12(41): 433-440.

[19] C. Nelson, and C. Plosser (1982). Trends and Random Walks In Macroeconmic Time Series: Some Evidence and Implications. Journal of Monetary Economics 10 (I 982) 139-162. North-Holland Publishing Company

20] D. N. Gugarati, D. N. (2004). Basic Econometrics, $4^{\text {th }}$ edition, TheMcGraw-Hill Companies, http://www.afriheritage.org/TTT/2\%20Basic\%20Eco nometrics\%20-\%20Gujarati[1].pdf

[21] G. C. Reinsel, and Sung, R. A. (1992). Vector Autoregressive Models with Unit Root and Reduced Rank Structure: Estimation, Likelihood Ratio Test and Forecasting. Journal of Time Series Analysis, $13: 353-375$.

[22] Lutkepohl Helmut (2005). New Introduction to Multiple Time Series Analysis, 2st Edition Pp. 1 - 191.
[23] D. O. Gudeta, Arero, B. G. and A. T. Goshu (2017). "Vector Autoregressive Modelling of Some Economic Growth Indicators of Ethiopia" American Journal of Economics, 7(1): 46-62

[24] W. Enders, (1995). Applied Econometric Time Series. $4^{\text {th }}$ edition, Wiley Publishers.

https://www.academia.edu/25270301/Applied_Econo metrics_Time_Series_4th_edition

[25] C.W.J Granger, Newbold, P. (1974). Spurious regression in econometrics. Journal of Econometrics, 2: 111 120.

[26] O. F. Anowor, Ukweni, N. O. and I., Martins, (2013). The impact of trade liberalisation on

Nigeria agricultural sector. Journal of Economics and Sustainable Development, 4(8): 14-24.

[27] N. Verter, and V., Becvarova (2016): The Impact Of Agricultural Exports On Economic Growth In Nigeria. Acta Universitatis Agriculturae Et Silviculturae Mendelianae Brunensis 64(81): 692700

[28] M. G. Ojide, Ojide, K. C. And Ogbodo, J. C.(2014). Export- led growth hypothesis in Nigeria: Applications of ARDL model and co-integration analysis. Global Journal of Emerging Market Economies, 6(1): 5-13

[29] .N. H. Shombe, (2008). Causality relationships between total exports with agricultural and manufacturing GDP in Tanzania. Institute of Development Economies, Discussion paper No. 136.

[30] E. Bbaale, and J. Mutenyo (2011). Export composition and economic growth in Sub- Saharan Africa: A panel analysis. Consilience: The Journal of Sustainable Development, 6(1): 1-19.

[31] E. J. Ojo, Awe I. T., Ogunjobi, J. O. (2014). Agricultural export and economic growth in Nigeria: A multivariate Johansen cointegration analysis. 